\title{
DIVERGENCE OF PER CAPITA REAL GROSS STATE PRODUCT BY SECTOR 1963 to 1986
}

\author{
Orley M. Amos, Jr.*
}

\begin{abstract}
This paper examines the divergence of per capita real gross state product in the United States from 1963 to 1986 . By extending earlier analyses of increasing regional income inequality, this paper hypothesizes that regional inequality is increasing due to the existence of a 100-year growth pole cycle that relies on the emergence of major product innovations. Each growth pole cycle, leading to separate 50-year periods of increasing, then decreasing, regional inequality, is hypothesized to generate recent increases in inequality. Regression analysis, using gross state product data, indicates that three sectors-transportation, communications, and public utilities; retail trade; and finance, insurance, and real estate-are the leading sectors for the onset of increasing regional inequality.
\end{abstract}

\section{INTRODUCTION}

This paper represents an extension of earlier analyses into the existence and causes of increasing regional income variation in the United States. In Amos (1988), empirical analyses of different data sets indicate that regional income variation in the United States began increasing in the mid-1970s. In later works, Amos $(1989,1990)$ explores the theoretical causes of increasing regional income variation. Empirical evidence suggests that regional income variation, both intrastate/intercounty and intranational/interstate, has been increasing since the mid1970s. Theoretical analysis suggests that recent increases in regional income variation is part of a long-term, endogenous, recurring pattern of increasing and decreasing regional inequality.

An extension of the theoretical analysis contained in Amos (1990) indicates that the increase in regional income variation beginning in the 1970 s is attributable to one or more leading sectors stimulated by the emergence of major technological innovations. Moreover, there are strong indications that increasing regional income variation is not driven by manufacturing activity, as was the case in earlier historical periods. With these indications in mind, I propose to examine the underlying causes of increasing regional income variation through a cross-sectional examination of industrial sectors. It is hypothesized that increasing varia-

\footnotetext{
*Professor of Economics, Oklahoma State University. Presented at the Southern Regional Science Association Meetings, Washington, D.C., March 23, 1990.
} 
tion between states at the aggregate level will be preceded by increasing variation for production sectors leading the resurgence of activity.

This analysis is made possible by the recent publication of gross state product from 1963 to 1986 for disaggregated sectors by the Bureau of Economic Analysis. This time series allows a previously unavailable analysis of the patterns of regional production by sectors using a consistent data set.

The two objectives of this research are to examine the hypothesized phenomenon of increasing regional income variation using previously untapped data, and to examine the contributions to regional income variation from the 12 basic industrial sectors.

\section{EXPECTATIONS}

The variation of regional activity and the related topic of income inequality have been subjected to theoretical and empirical analyses since Kuznets (1955) developed the noted inverted-U hypothesis. This hypothesis states that increasing inequality in the early stages of economic development is followed by declining inequality in later stages. Empirical tests generally supporting Kuznets' hypothesis generate expectations of intranational convergence of economic activity (both among the general population and across regions) for more developed countries.

The convergence pattern is expected from neoclassical economic growth theory, which implies that factor mobility generates factor market equalization, overcoming inequalities generated by the early stages of the industrial revolution, opening of new territories, and/or major product innovations. Neoclassical growth theory implies that convergence results in equality and, in all likelihood, long-run stability, until another exogenous occurrence such as the industrial revolution throws the economy out of equilibrium. Without an exogenous occurrence, growth is expected to continue along a long-range path of stability, with all regions expanding at the same growth rate.

There is mounting evidence that regional income variation has increased in recent years without the onset of an exogenous shock comparable to the industrial revolution. Empirical analysis of per capita income among counties within states by Amos (1988) indicates that regional income variation has been on the rise since the 1970s. Using data and methodology originally presented in Williamson (1965), Amos's analysis (1984) of per capita income variation among states within the country also shows signs of increasing since the mid-1970s.

The critical question addressed in this analysis is why regional inequality has increased. A preliminary theoretical explanation is offered in Amos (1989) and is 
developed more thoroughly in Amos (1990). In these analyses, regional income variation is the consequence of differential rates of regional growth that are attributed to recurring, endogenous long-wave-inducing growth pole cycles.

Growth pole cycles are 100-year cycles generated by the periodic development of major technological innovations that first lead to the concentration of activity into growth poles. The concentration of activity generates a 50-year long wave through the stimulation of investment in capital infrastructure. Technological innovations then lead to the dispersion of activity from the growth pole to surrounding areas, generating a second 50-year long wave through the stimulation of additional investment in capital infrastructure. According to this explanation, regional income variation increases through the 50-year polarization long wave, then declines through the 50-year dispersion long wave. Kuznets' (1955) inverted-U of personal inequality and Williamson's (1965) inverted-U of regional inequality are two consequences of the 100-year growth pole cycle.

One key empirical problem associated with the growth pole cycle is that the dominant growth pole itself is likely to shift from one location to the next with the emergence of each new growth pole cycle, thus creating problems in the actual measurement of regional inequality across growth cycles. Although human civilization is hypothesized to have experienced numerous growth pole cycles, the outward spread inherent with each new growth pole indicates that any specific geographic region experiences each growth pole cycle in a different way, preventing the explicit identification of a continuous, cyclical pattern. Although civilization as a whole exhibits the growth pole cycle, any given location is besieged by a series of apparently exogenous and random occurrences from the underlying cycle.

Thus, Kuznets and Williamson's inverted-U patterns are noted for a particular country at the center of a given growth pole cycle. This position was held by the United States over the past 100 years (1880s to 1980s), making the inverted-U pattern more readily observed in the United States than in other countries. In the preceding 100 years (1780s to 1880s), Europe was the center of the growth pole cycle, implying the inverted-U pattern would have been most obvious in Europe during that period if data were available to measure the phenomenon.

Areas further removed from the center of the growth pole follow the inverted-U pattern to lesser degrees, depending on how far removed they are in physical and economic distances. Transportation and communication systems enhance interaction between areas and reduce the economic distance for a given physical distance. Lines of interaction through the global urban hierarchy provide the central method of transmitting the growth pole cycle stimulus. Thus, countries and/or regions that are economically removed from the growth pole, and thus fur- 
ther down the global urban hierarchy, will exhibit the inverted-U pattern to a lesser degree than the growth pole itself, and the pattern will be lagged several years, or even decades, over time. At the extreme, the growth impulses may fail to reach some areas of the globe during a given growth pole cycle. As the global economy becomes more interdependent, the inverted-U patterns for all countries will become more distinct and coincident.

The theoretical analysis in Amos (1990) suggests that the recent occurrence of increasing regional variation is generated by the emergence of a new growth pole cycle continuing until the late 21 st century. The growth pole for this cycleJapan in all likelihood-has been generating a surge of productive growth throughout the global urban hierarchy, leading to a concentration of productive activity, capital, wealth, and income in a series of dominant growth centers worldwide. This productive surge generates a greater rate of growth at the growth centers and thus generates an increase in regional variation between the growth centers and the rest of the country. According to this theory, concentration and increasing regional inequality will continue for 50 years, until approximately 2020 or 2030. The United States, although not the center of this growth pole cycle, is linked closely enough with Japan that it should exhibit a distinct inverted-U pattern over the next century.

The theory further implies that the productive surge underlying the growth pole cycle is tied to a small number of growth pole industries stimulated by the development of one or more major technological innovations. Approximately 200 years ago the innovation was the steam engine, leading first to productive concentration (especially in manufacturing activity), then later to dispersive activity through the railroad system. The internal combustion engine was the major innovation of 100 years ago, leading initially to improved urban transportation and productive efficiency and later to dispersive activity through automobiles, trucks, and the interstate highway system.

The best candidate for the most recent growth pole cycle innovation is the silicon chip, which has enabled major advances in computer technology and information processing during the last decade. These advances have further surfaced in improved productivity and efficiency of administrative activities located in cities. Although only speculative at this point, the growth pole cycle theory implies that the silicon chip and computer technology will be adapted to dispersive activity in 40 or 50 years. While it can be argued that the silicon chip has led to improved information distribution in conjunction with fiber optics and satellite communications, the primary emphasis has been on investment in capital goods used to process information (computers) rather than to distribute information. The particular form that the dispersive silicon chip technology might take is unknown at this point, in the same way that the extent of the railroad system was hard to an- 
ticipate with the invention of the steam engine in the late $1700 \mathrm{~s}$, or the interstate highway system with the invention of the internal combustion engine in the late 1800 s.

The silicon chip has generated a significant impact on the world economy since its invention in the 1960s. Leading the way in computers, electronic equipment, and other goods using silicon chip technology is Japan. Japan has grown fast, becoming a leading world power equal to the United States in this regard. Japan has most of the largest banks and corporations in the world and is the major exporter of goods and services worldwide. Growth surges driven by Japan filter down the global urban hierarchy into U.S. cities/growth centers, which then drive the U.S. economy. Regional income inequality in the United States is thus on the rise as a result of this growth pole cycle force.

Moreover, it is anticipated that the industrial sectors driving rising inequality are centrally connected with silicon chip and computer technologies. These industries are expected to lead the rest of the economy in terms of growth. As leading sectors, they are expected to exhibit increasing regional variation before the economy as a whole.

\section{METHODOLOGY}

Gross state product data for each state, by sector, from 1963 to 1986 is subjected to statistical analysis using the following equation:

$$
G R_{i s}=\alpha+\beta_{1} G 63_{i s}+\beta_{2}\left(G 63_{i s}\right)^{2}+\varepsilon_{i s}
$$

where $\mathrm{GR}_{\mathrm{is}}=$ the growth rate of per capita real gross state product from 1963 to 1986 for sector $\mathrm{i}$, state s; and $\mathrm{G} 63_{\text {is }}=$ per capita real gross state product in 1963 for sector i, state s. Initially, separate cross-sectional equations are estimated for per capita real gross state product and per capita real product for each of ten standard industrial sectors (i) using observations for the 50 states (s). The industrial sectors subjected to analysis are agriculture, forestry, and fishery (AG); mining (MN); construction (CN); manufacturing (MF); transportation, communications, and public utilities (TC); wholesale trade (WT); retail trade (RT); finance, insurance, and real estate (FR); services (SR); and government (GV). Per capita real GSP is calculated for each sector by dividing real GSP estimates obtained from the Bureau of Economic Analysis by total population in the respective state. 
The quadratic specification of Equation (1) is expected to generate support for the hypothesized divergence of regional activity reported in Amos (1988) for per capita income. The linear version of Equation (1) has been used extensively to isolate convergence of regional growth. In its linear form without the quadratic term, convergence occurs if $\beta_{1}<0$, indicating that states with the lowest rates of per capita real GSP also have the highest rates of growth of per capita real GSP. The least developed states are thus "catching up" to the more developed states.

Inclusion of the quadratic term is used to test if convergence is strictly linear or $U$-shaped. Given $\beta_{1}<0$, renewed divergence of regional activity, after a period of convergence, is indicated if $\beta_{2}>0$. Moreover, given $\beta_{1}<0$ and $\beta_{2}>0$, particular attention is paid to the minimum value obtained by the quadratic function, and comparison of the minimum value with respect to actual values for per capital real GSP achieved between 1963 and 1986. The approximate year in which the minimum value is reached indicates whether the particular sector is leading or lagging in generation of increasing regional inequality.

\section{RESULTS}

Equation (1) is estimated using per capita real gross state product and per capita real gross product for each of the 12 standard production sectors defined above.

\section{Aggregate GSP}

Evidence of increasing regional variation is provided by estimation of Equation (1), using per capita real gross state product. Table 1 presents coefficients using OLS for both the full quadratic version of Equation (1) and, for purposes of comparison, the simple linear version that omits the quadratic term.

Table 1 generates two points of interest. First, the negative coefficient of G63 in the linear version of Equation (1) provides evidence of the general convergence of per capita real GSP among states since 1963. There is clearly a trend in which states with lower levels of per capita real GSP exhibited higher growth rates. However, the $\mathrm{R}^{2}$ for this equation is extremely low, suggesting that the linear specification does not tell the entire story.

Second, the full quadratic version of this equation achieves a much higher $\mathrm{R}^{2}$ than the linear version, with the signs of the linear and quadratic terms negative and positive, respectively. The values of the coefficients for $\mathrm{G} 63$ and $\mathrm{G} 63^{2}$ indicate that convergence may be occurring, but the overall pattern is U-shaped rather than linear. In essence, states with both the lowest and highest levels of per capita 
TABLE 1

Divergence of Per Capita Real Gross State Product, 1963-1986²

\begin{tabular}{lrrrr}
\hline \hline Constant & $\mathrm{G} 63$ & $\mathrm{G63}^{2}$ & $\mathrm{R}^{2}$ & Minimum \\
\hline 2.708 & -0.081 & -- & 0.096 & \\
$(8.193)^{\mathrm{b}}$ & $(-2.510)$ & -- & $(6.299)$ & \\
& & & & \\
5.274 & -0.531 & 0.018 & 0.225 & $\$ 14,994$ \\
$(5.860)$ & $(-3.509)$ & $(3.031)$ & $(8.271)$ & $(1986)^{\mathrm{c}}$ \\
& & & & \\
\hline
\end{tabular}

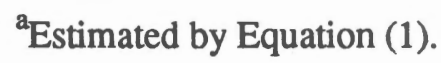

${ }^{\mathrm{b}} \mathrm{T}$-values in parentheses.

${ }^{c}$ Year estimated equation reaches its minimum value.

real GSP exhibit the highest rates of growth of real per capita GSP, with the lowest rates of growth found in states with middle levels of per capita real GSP.

Results of per capita real GSP presented in Table 1 suggest that state economies began diverging sometime between 1963 and 1986, consistent with conclusions reached in the study of per capita income in Amos $(1988,1989)$. An indication of the approximate turning point for the quadratic estimate of Equation (1) is found by calculating the level of per capita real GSP at which the equation achieves its minimum value. This estimated value of $\$ 14,916$, is approximately equal to per capita real GSP in 1986 , which is $\$ 14,994$, suggesting 1986 as the year in which per capita real GSP ceased converging and began to diverge.

Although the estimated turning point is within the data used for the analysis, it is about eight to ten years past other estimates of the turning point for per capita income (Amos 1988, 1989). However, given that per capita income and per capita real GSP are both indicative of general state activity, but measure different dimensions of the economy, this result is not totally unexpected.

\section{Sectoral GSP}

Insight of leading and lagging sectors associated with the divergence of per capital real GSP is obtained by estimating Equation (1), using per capita real GSP for each of ten industrial sectors. Equation (1) is separately estimated for agriculture, forestry, and fishery (AG); mining (MN); construction (CN); manufacturing (MF); transportation, communications, and public utilities (TC); wholesale trade (WT); retail trade (RT); finance, insurance, and real estate (FR); services (SR); 
and government (GV). As with per capita real GSP, Equation (1) is estimated in the simple linear and quadratic forms, with results presented in Table 2.

Results for the sectors presented in Table 2 can be divided into four categories. In the first category, two of the sectors (AG and GV) provide statistically significant evidence of divergence, with a negative coefficient for the linear term and a positive coefficient for the quadratic term. In both sectors, inclusion of the quadratic term improves the explanatory power over the simple linear equation. The second category includes four sectors (MF, TC, RT, and FR), which exhibit U-shaped patterns in the quadratic equations, but the quadratic terms are not statistically significant at the 0.05 level. In each case the explanatory power of the quadratic equation is only slightly better than the linear equation which provides evidence for convergence. The third category includes three sectors (MN, CN, and SR), which exhibit no statistical significance in either the linear or quadratic versions of Equation (1). The final category includes a single sector (WT), which shows statistically significant convergence in the linear equation, but no statistical significance in the quadratic equation.

These results provide evidence for conventional expectations of the convergence of per capita real GSP for all but the mining, construction, and service sectors. The growth rate in these three sectors is predominately influenced by factors other than the level of per capita real GSP in the sector. In accordance with conventional expectations, the majority of the sectors are, at the very least, converging. However, there is also evidence that agriculture and government sectors are diverging, and that there is less support for divergence in manufacturing, transportation, retail trade, and finance sectors. The only sector exhibiting unquestioned convergence is wholesale trade.

Further insight into the divergence of regional activity is achieved by calculating the minimum value for each quadratic equation exhibiting the U-shaped pattern. These values are also presented in Table 2 . Of some importance are five of the eight sectors that achieve minimum values occurring after the latest year of observation, indicating that convergence may be slowing, but has not yet turned to divergence. However, three of the sectors (TC, RT, and FR) have minimum values that occur within the observation range. In particular, the transportation, communications, and public utility sector reaches a minimum at $\$ 997$, a value corresponding to the national average of per capita real GSP occurring in that sector in 1974. The retail trade sector reaches a minimum value corresponding to the year 1984, and the finance, insurance, and real estate sector obtains its minimum near 1972.

Although conclusions are only speculative at this point, a case can be made for each of these three sectors experiencing rapid growth due to advances in computer technology. Advances in computer technology and information processing 
TABLE 2

Divergence of Per Capita Real Gross State Product by Sector, 1963-1986 ${ }^{\mathrm{a}}$

\begin{tabular}{|c|c|c|c|c|c|}
\hline Sector & Constant & G63 & $\mathrm{G}_{63}{ }^{2}$ & $\mathbf{R}^{2}$ & Minimum \\
\hline \multirow[t]{2}{*}{ Agriculture } & $\begin{array}{c}0.436 \\
(1.503)^{b}\end{array}$ & $\begin{array}{r}0.127 \\
(0.274)\end{array}$ & $\overline{--}$ & $\begin{array}{l}-0.081 \\
(0.075)\end{array}$ & \\
\hline & $\begin{array}{r}1.394 \\
(3.201)\end{array}$ & $\begin{array}{r}-3.831 \\
(-2.603)\end{array}$ & $\begin{array}{r}2.491 \\
(2.814)\end{array}$ & $\begin{array}{r}0.107 \\
(4.003)\end{array}$ & $\begin{array}{r}\$ 769 \\
--\end{array}$ \\
\hline \multirow[t]{2}{*}{ Mining } & $\begin{array}{r}-0.712 \\
(-0.566)\end{array}$ & $\begin{array}{r}-0.109 \\
(-0.153)\end{array}$ & -- & $\begin{array}{r}-0.020 \\
(0.024)\end{array}$ & \\
\hline & $\begin{array}{r}-0.665 \\
(-0.481)\end{array}$ & $\begin{array}{r}-0.260 \\
(-0.137)\end{array}$ & $\begin{array}{r}0.021 \\
(0.086)\end{array}$ & $\begin{array}{r}-0.041 \\
(0.015)\end{array}$ & -- \\
\hline \multirow[t]{2}{*}{ Construction } & $\begin{array}{r}-1.710 \\
(-3.042)\end{array}$ & $\begin{array}{r}0.529 \\
(0.992)\end{array}$ & -- & $\begin{array}{r}-0.000 \\
(0.984)\end{array}$ & \\
\hline & $\begin{array}{r}-2.194 \\
(-1.491)\end{array}$ & $\begin{array}{r}1.328 \\
(0.574)\end{array}$ & $\begin{array}{r}-0.278 \\
(-0.355)\end{array}$ & $\begin{array}{r}-0.018 \\
(0.547)\end{array}$ & $\begin{array}{l}-- \\
--\end{array}$ \\
\hline \multirow[t]{2}{*}{ Manufacturing } & $\begin{array}{r}4.168 \\
(9.444)\end{array}$ & $\begin{array}{r}-0.900 \\
(-3.807)\end{array}$ & $=$ & $\begin{array}{r}0.213 \\
(14.497)\end{array}$ & \\
\hline & $\begin{array}{r}4.879 \\
(6.227)\end{array}$ & $\begin{array}{r}-1.871 \\
(-2.044)\end{array}$ & $\begin{array}{r}0.256 \\
(1.097)\end{array}$ & $\begin{array}{r}0.216 \\
(7.881)\end{array}$ & $\$ 3,652$ \\
\hline $\begin{array}{l}\text { Transportation, } \\
\text { communication, } \\
\text { and public utilities }\end{array}$ & $\begin{array}{r}3.625 \\
(10.445) \\
6.026 \\
(7.089)\end{array}$ & $\begin{array}{r}-1.382 \\
(-3.087) \\
-7.669 \\
(-3.648)\end{array}$ & $\begin{array}{r}-- \\
\overline{-} \overline{-} \\
(1.260)\end{array}$ & $\begin{array}{r}0.146 \\
(9.532) \\
0.270 \\
(10.227)\end{array}$ & $\begin{array}{c}\$ 997 \\
(1974)^{c}\end{array}$ \\
\hline \multirow[t]{2}{*}{ Wholesale trade } & $\begin{array}{r}4.830 \\
(11.935)\end{array}$ & $\begin{array}{r}-3.311 \\
(-4.036)\end{array}$ & $=-$ & $\begin{array}{r}0.234 \\
(16.288)\end{array}$ & \\
\hline & $\begin{array}{r}4.230 \\
(3.512)\end{array}$ & $\begin{array}{r}-0.912 \\
(-0.198)\end{array}$ & $\begin{array}{r}-2.197 \\
(-0.530)\end{array}$ & $\begin{array}{r}0.223 \\
(8.165)\end{array}$ & $\begin{array}{l}-- \\
--\end{array}$ \\
\hline Retail trade & $\begin{array}{r}4.311 \\
(9.785) \\
6.325 \\
(3.796)\end{array}$ & $\begin{array}{r}-2.453 \\
(-4.923) \\
-7.019 \\
(-1.909)\end{array}$ & $\begin{array}{r}-- \\
2 \overline{-514} \\
(1.253)\end{array}$ & $\begin{array}{r}0.317 \\
(24.234) \\
0.325 \\
(13.043)\end{array}$ & $\begin{array}{l}\$ 1,396 \\
(1984)\end{array}$ \\
\hline \multirow[t]{2}{*}{$\begin{array}{l}\text { Finance, insurance, } \\
\text { and real estate }\end{array}$} & $\begin{array}{r}3.726 \\
(11.741)\end{array}$ & $\begin{array}{r}-0.899 \\
(-3.375)\end{array}$ & -- & $\begin{array}{r}0.172 \\
(11.393)\end{array}$ & \\
\hline & $\begin{array}{r}5.113 \\
(4.767)\end{array}$ & $\begin{array}{r}-3.444 \\
(-1.813)\end{array}$ & $\begin{array}{r}1.103 \\
(1.103)\end{array}$ & $\begin{array}{r}0.186 \\
(6.708)\end{array}$ & $\begin{array}{l}\$ 1,562 \\
(1972)\end{array}$ \\
\hline \multirow[t]{2}{*}{ Services } & $\begin{array}{r}3.162 \\
(18.273)\end{array}$ & $\begin{array}{r}-0.127 \\
(-0.929)\end{array}$ & $\begin{array}{l}-- \\
--\end{array}$ & $\begin{array}{l}-0.002 \\
(0.863)\end{array}$ & \\
\hline & $\begin{array}{r}2.668 \\
(5.778)\end{array}$ & $\begin{array}{r}0.534 \\
(0.907)\end{array}$ & $\begin{array}{r}-0.149 \\
(-1.154)\end{array}$ & $\begin{array}{r}0.004 \\
(1.101)\end{array}$ & -- \\
\hline \multirow[t]{2}{*}{ Government } & $\begin{array}{r}1.113 \\
(7.211)\end{array}$ & $\begin{array}{r}-0.130 \\
(-1.848)\end{array}$ & $=-$ & $\begin{array}{r}0.046 \\
(3.416)\end{array}$ & \\
\hline & $\begin{array}{r}2.527 \\
(11.304)\end{array}$ & $\begin{array}{r}-1.397 \\
(-7.670)\end{array}$ & $\begin{array}{r}0.127 \\
(7.224)\end{array}$ & $\begin{array}{r}0.533 \\
(29.584)\end{array}$ & $\begin{array}{r}\$ 5,490 \\
--\end{array}$ \\
\hline
\end{tabular}

\footnotetext{
${ }^{a}$ Estimated by Equation (1).

${ }^{\mathrm{B}} \mathrm{T}$-values in parentheses.

${ }^{c}$ Year estimated equation reaches its minimum value.
} 
are certainly expected to surface in the transportation, communications, and public utilities sector. Moreover, the introduction of automated tellers and computerized information processing has had a tremendous impact on the finance, insurance, and real estate sector. The retail trade sector has also benefitted from computerized scanning equipment. The one surprising point is that a similar result did not arise for the services sector. The heterogeneity of this sector may have prevented the generation of any meaningful results.

In support of the theoretical discussion presented earlier, the results suggest that the TC, RT, and FR sectors may be leading the economy in the divergence of per capita real GSP as noted in Table 1, and in all likelihood have triggered the increase of regional income inequality reported by $\operatorname{Amos}(1988,1989)$. It is also worth noting that the traditional economic base sectors studied in regional analysis-agriculture, mining, manufacturing, and government-do not exhibit a leading role in the onset of diverging GSP. Although these may have been the leading economic base sectors in previous growth pole cycles, they are apparently giving way to new technologies that are contained in sectors previously not considered as economic base activities.

\section{Disaggregated Sectoral Analysis}

Evaluation of the ten standard industrial sectors presented in Table 2 is suggestive of leading sectors underlying the divergence of gross state product in recent years, and also indicative of the need for more detailed analysis. The same type of analysis contained in Table 2 is also performed on per capita real gross state product for 58 industrial subsectors. Using BEA specifications, each of the ten standard industrial sectors is divided into the following subsectors: agriculture, forestry, and fisheries-2; mining-4; manufacturing-21 (11 in durable manufacturing and 10 in nondurable manufacturing); transportation, communication, and public utilities-9; finance, insurance, and real estate-6; services-13; and government -3 . Construction, wholesale trade, and retail trade are not divided into more narrowly defined subsectors.

Particular attention is paid to the two sectors exhibiting U-shaped relationships in Table 2 having minimum values estimated to fall within the range of the data set (transportation, communication, and public utilities and finance, insurance, and real estate). It is expected that the disaggregated sectors will exhibit a clearer indication of the leading sectors underlying the increase in regional inequality.

Of the 58 disaggregated sectors subjected to analysis, eight exhibited Ushaped relationships for Equation (1) and generated minimum values for per capita real gross state product between 1963 and 1986. Estimated equations for 
these eight sectors-machinery, instruments, communication, banking, holding companies, insurance carriers, health services, and state and local governmentsare presented in Table 3. The estimated years in which the minimum values are reached are health services-1968, communication-1973, banking-1976, insurance carriers-1978, state and local governments-1973, holding companies1982, instruments-1982, and machinery-1984.

Analysis of the disaggregated sectors in Table 3 reinforces and refines earlier conclusions reached from Table 2. Communication, banking, insurance carriers, and holding companies appear to be the specific leading sectors contained in the more aggregate transportation, communication, and public utilities and finance, insurance, and real estate sectors. The existence of instruments as a leading sector is also consistent with earlier expectations for the underlying role played by advances in computer technology. However, health services, state and local government, and machinery do not appear to be consistent with these expectations.

Of the remaining disaggregated sectors, 16 generate statistically significant U-shaped relationships for Equation (1), but contain estimated minimum values that are beyond the range of observation. The first column of Table 4 lists these sectors. Seven of these sectors are in manufacturing, three in transportation, and four in services. The existence of a significant $U$-shape pattern, without reaching the minimum, suggests that these sectors are on the brink of diverging; in all possibility they are being lead by the eight sectors contained in Table 3 . The second column of Table 4 presents 17 sectors that exhibit statistically significant evidence of convergence with no evidence of a U-shaped relationship. Seven of these sectors are in manufacturing and four are in services. The third column of Table 4 lists the remaining 16 sectors, which exhibit no clear statistically significant pattern of either convergence or divergence. These sectors, including several in the mining, service, and government categories, are evidently influenced by other exogenous factors.

Evidence presented in Tables 3 and 4 for the disaggregated sectors suggests that the "traditional" leading sectors in manufacturing are not leading the resurgence of growth that has generated increased regional inequality in this country. The new leading sectors appear to be in the communication and financial sectors. Although these results are not unambiguous, they are consistent with the proposition that increasing regional variation is caused by advances in computer technology consistent with the emergence of a new growth pole cycle. 
TABLE 3

Divergence of Per Capita Real Gross State Product by Leading Sectors, $1963-1986^{\mathrm{a}}$

\begin{tabular}{|c|c|c|c|c|c|}
\hline Sector & Constant & G63 & $\mathrm{G} 63^{2}$ & $\mathrm{R}^{2}$ & Minimum \\
\hline \multirow[t]{2}{*}{ Machinery } & $\begin{array}{r}8.925 \\
(18.635)^{b}\end{array}$ & $\begin{array}{l}-12.860 \\
(-5.753)\end{array}$ & $\begin{array}{l}-- \\
--\end{array}$ & $\begin{array}{r}0.391 \\
(33.096)\end{array}$ & \\
\hline & $\begin{array}{r}9.540 \\
(15.894)\end{array}$ & $\begin{array}{l}-24.644 \\
(-3.301)\end{array}$ & $\begin{array}{l}23.391 \\
(1.651)\end{array}$ & $\begin{array}{r}0.412 \\
(18.494)\end{array}$ & $\begin{array}{r}\$ 327 \\
(1984)^{c}\end{array}$ \\
\hline \multirow[t]{2}{*}{$\begin{array}{l}\text { Instruments and } \\
\text { related products }\end{array}$} & $\begin{array}{r}7.786 \\
(8.794)\end{array}$ & $\begin{array}{l}-41.871 \\
(-1.994)\end{array}$ & -- & $\begin{array}{r}0.056 \\
(3.977)\end{array}$ & \\
\hline & $\begin{array}{r}8.448 \\
(8.007)\end{array}$ & $\begin{array}{r}-112.176 \\
(-1.729)\end{array}$ & $\begin{array}{r}598.476 \\
(1.145)\end{array}$ & $\begin{array}{r}0.062 \\
(2.656)\end{array}$ & $\begin{array}{r}\$ 94 \\
(1982)\end{array}$ \\
\hline \multirow[t]{2}{*}{ Communication } & $\begin{array}{r}5.531 \\
(15.180)\end{array}$ & $\begin{array}{r}-4.215 \\
(-1.441)\end{array}$ & -- & $\begin{array}{r}0.021 \\
(2.077)\end{array}$ & \\
\hline & $\begin{array}{r}8.126 \\
(10.588)\end{array}$ & $\begin{array}{l}-40.907 \\
(-4.020)\end{array}$ & $\begin{array}{r}107.292 \\
(3.730)\end{array}$ & $\begin{array}{r}0.225 \\
(8.268)\end{array}$ & $\begin{array}{r}\$ 191 \\
(1973)\end{array}$ \\
\hline \multirow[t]{2}{*}{ Banking } & $\begin{array}{r}4.610 \\
(6.495)\end{array}$ & $\begin{array}{l}-13.298 \\
(-2.391)\end{array}$ & $\begin{array}{l}-- \\
--\end{array}$ & $\begin{array}{r}0.086 \\
(5.719)\end{array}$ & \\
\hline & $\begin{array}{r}8.008 \\
(5.184)\end{array}$ & $\begin{array}{l}-63.659 \\
(-2.996)\end{array}$ & $\begin{array}{r}164.700 \\
(2.447)\end{array}$ & $\begin{array}{r}0.171 \\
(6.145)\end{array}$ & $\begin{array}{r}\$ 708 \\
(1976)\end{array}$ \\
\hline \multirow[t]{2}{*}{ Holding companies } & $\begin{array}{r}5.608 \\
(17.105)\end{array}$ & $\begin{array}{l}-17.792 \\
(-1.899)\end{array}$ & $\begin{array}{l}-- \\
--\end{array}$ & $\begin{array}{r}0.050 \\
(3.607)\end{array}$ & \\
\hline & $\begin{array}{r}6.559 \\
(13.884)\end{array}$ & $\begin{array}{l}-74.901 \\
(-3.230)\end{array}$ & $\begin{array}{r}416.209 \\
(2.663)\end{array}$ & $\begin{array}{r}0.155 \\
(5.575)\end{array}$ & $\begin{array}{r}\$ 90 \\
(1982)\end{array}$ \\
\hline \multirow[t]{2}{*}{ Insurance carriers } & $\begin{array}{r}3.809 \\
(11.689)\end{array}$ & $\begin{array}{r}-1.509 \\
(-2.303)\end{array}$ & $\begin{array}{l}-- \\
--\end{array}$ & $\begin{array}{r}0.079 \\
(5.303)\end{array}$ & \\
\hline & $\begin{array}{r}5.522 \\
(10.693)\end{array}$ & $\begin{array}{l}-53.471 \\
(-4.601)\end{array}$ & $\begin{array}{r}218.534 \\
(3.980)\end{array}$ & $\begin{array}{r}0.293 \\
(11.376)\end{array}$ & $\begin{array}{r}\$ 122 \\
(1978)\end{array}$ \\
\hline \multirow[t]{2}{*}{ Health services } & $\begin{array}{r}5.344 \\
(15.442)\end{array}$ & $\begin{array}{r}-4.763 \\
(-3.548)\end{array}$ & $\begin{array}{l}-- \\
--\end{array}$ & $\begin{array}{r}0.188 \\
(12.590)\end{array}$ & \\
\hline & $\begin{array}{r}7.619 \\
(8.952)\end{array}$ & $\begin{array}{l}-23.532 \\
(-3.556)\end{array}$ & $\begin{array}{l}35.956 \\
(2.888)\end{array}$ & $\begin{array}{r}0.294 \\
(11.409)\end{array}$ & $\begin{array}{r}\$ 327 \\
(1968)\end{array}$ \\
\hline \multirow[t]{2}{*}{ State and local } & $\begin{array}{r}2.694 \\
(7.700)\end{array}$ & $\begin{array}{r}-1.170 \\
(-2.376)\end{array}$ & $\begin{array}{l}-- \\
--\end{array}$ & $\begin{array}{r}0.085 \\
(5.647)\end{array}$ & \\
\hline & $\begin{array}{r}7.414 \\
(8.290)\end{array}$ & $\begin{array}{r}-14.241 \\
(-5.964)\end{array}$ & $\begin{array}{r}8.589 \\
(5.548)\end{array}$ & $\begin{array}{r}0.431 \\
(19.930)\end{array}$ & $\begin{array}{r}\$ 829 \\
(1973)\end{array}$ \\
\hline
\end{tabular}

${ }^{a}$ Estimated by Equation (1).

b T-values in parentheses.

${ }^{c}$ Year estimated equation reaches its minimum value. 
TABLE 4

Classification of Disaggregated Sectors

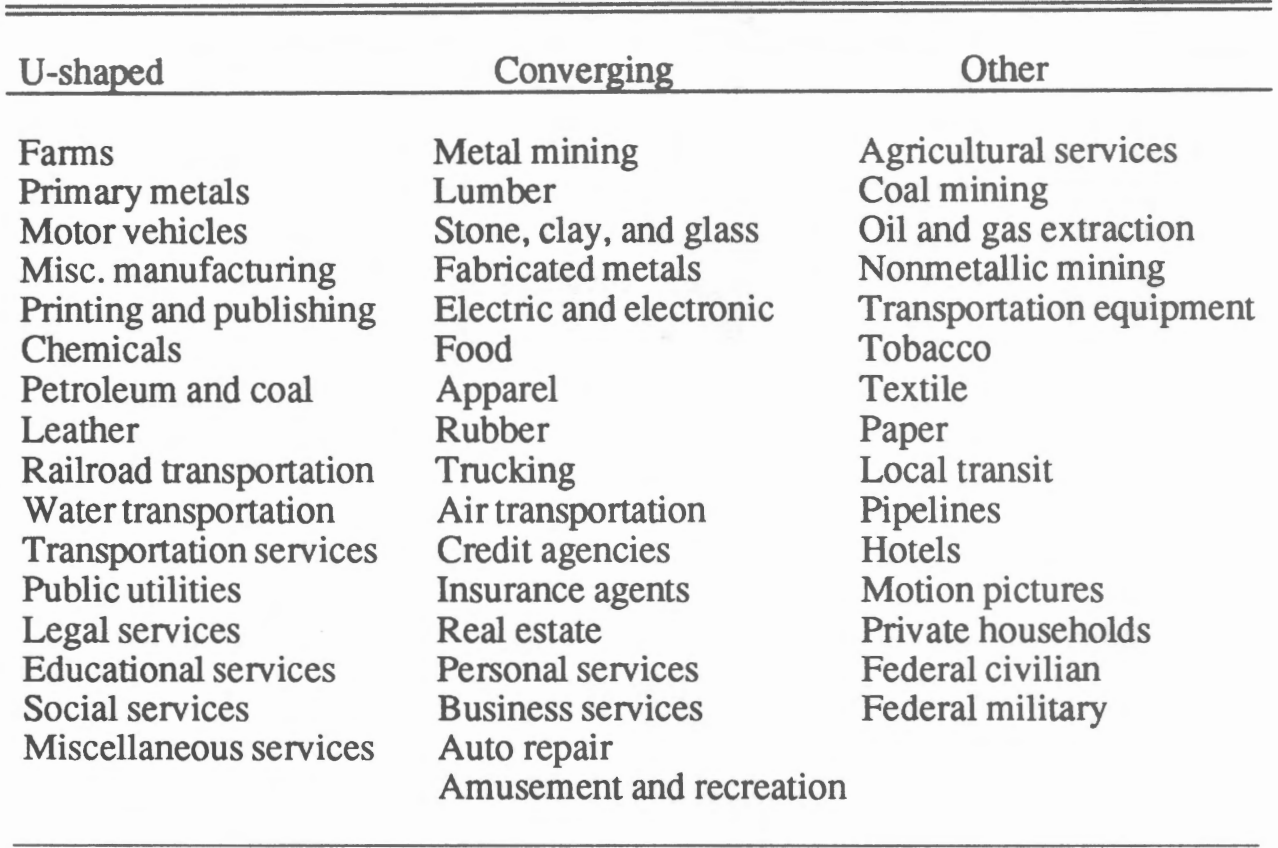

\section{v. CONCLUSIONS}

This analysis provides support for the proposition that regional variation in the United States has been increasing in recent years. In particular, the results indicate that three standard sectors-transportation, communications, and public utilities; retail trade; and finance, insurance, and real estate-are leading the increase of regional variation. Consistent with these results is the theoretical explanation that the increase in regional variation is attributable to advances in computer technologies made possible by the invention of the silicon chip.

It is worth emphasizing that manufacturing did not surface as a leading sector in the generation of increased regional variation. Although manufacturing was undoubtedly the leading sector in the previous growth pole cycle in the United States, and perhaps the second most recent cycle in Europe, it has evidently given way to other sectors.

Disaggregate sector analysis indicates that eight sectors are likely candidates for leading sector status in the emergence of a new growth pole cycle. The potential leading sectors that surface as being affected by the computer revolution are communication, banking, and health services. Clearly, more analysis of this process is warranted. 
From a regional policy perspective, the traditional economic base sectorsagriculture and manufacturing-are not likely to be the leading driving forces for local economies into the next century as they were in the last. Regions that acquire communications, retail trade, finance, and insurance sectors as economic base activities are likely to do much better than regions with traditional economic base activities. The irony of this conclusion is that each of these three sectors has traditionally been considered a local activity driven by the traditional economic base sectors. However, technological advances in computers and information processing have apparently changed the nature of these industries, creating basic sectors out of local activities.

\section{REFERENCES}

Amos, Orley M. "Unbalanced Regional Growth and Regional Income Inequality in the Latter Stages of Development." Regional Science and Urban Economics 18 (1988): 549-566.

. "An Inquiry into the Causes of Increasing Regional Income Inequality in the United States." The Review of Regional Studies 19 (1989): 1-12. . "Growth Pole Cycles: A Synthesis of Growth Pole and Long Wave Theories." The Review of Regional Studies 20 (1990): 37-48.

Kuznets, Simon. "Economic Growth and Income Inequality." American Economic Review 45 (1955): 1-28.

Williamson, Jeffery G. "Regional Inequality and the Process of National Development: A Description of the Patterns." Economic Development and Cultural Change 13 (1965): 3-45. 